\title{
"Screening at the door" - continuous rapid molecular screening for MRSA at emergency department is efficacious and effective
}

\author{
BSP Ang ${ }^{1 *}$, SY Tay ${ }^{2}$, M Umayam³ ${ }^{3}$ BF Poh ${ }^{4}$, PU Krishnan ${ }^{3}$ \\ From 3rd International Conference on Prevention and Infection Control (ICPIC 2015) \\ Geneva, Switzerland. 16-19 June 2015
}

\section{Introduction}

MRSA is highly prevalent in Singapore hospitals. MRSA bacteremia is being monitored by Ministry of Health $(\mathrm{MOH})$ and will become a key performance indicator from 2015.

TTSH is a 1600 bedded hospital with the second busiest emergency department in the country. The majority of patients are in open, multi-bedded wards and shared facilities.

Many strategies including active surveillance for MRSA and cohorting of patients have been in place for several years. Patients are screened on admission, and positive patients transferred to cohort wards with substantial resource wastage as well as increased chances of transmission.

\section{Objectives}

The objective of this study was to see if implementation of rapid molecular screening for MRSA before admission would improve cohorting, reduce post-admission transfers and MRSA infection rates.

\section{Methods}

Estimates of time and effort spent on transferring of patients were made by observation and questioning of nursing and medical staff.

We implemented screening for MRSA at the Emergency department in 2012, using polymerase chain reaction $(\mathrm{PCR})$ after setting up a satellite laboratory just next to the ED. Patients confirmed for admission had nasal swabs done by trained medical technicians who then did the PCR test. Results were ready within 2 -3 hrs and routed to Bed Management Unit who then assigned patients to appropriate wards.

\section{Results}

Each patient transfer entailed an average of 155 min of nursing and housekeeping and $30 \mathrm{~min}$ of doctor's time. After implementation of screening before bed assignment, there was reduction in transfers of patients to cohort wards from $8 \%$ to $2 \%$ of all admissions (OR 0.23 ; $95 \% \mathrm{CI}$ $0.19,0.29 ; \mathrm{P}=0.0000$ ).

Comparing 2014 to 2012, there was a $22 \%$ reduction in MRSA bacteremia rates (OR 0.78; 95\% CI 0.53, 1.14; $P=0.1853)$.

\section{Conclusion}

Continuous rapid molecular screening for MRSA at Emergency Department is Efficacious and Effective in reducing transfers and MRSA bacteremia rates and has been sustainable.

\section{Disclosure of interest}

None declared.

\section{Authors' details}

${ }^{1}$ Infectious Diseases, Tan Tock Seng Hospital, Singapore, Singapore.

2Emergency, Tan Tock Seng Hospital, Singapore, Singapore. ${ }^{3}$ Laboratory Medicine, Tan Tock Seng Hospital, Singapore, Singapore. ${ }^{4}$ Infection Control, Tan Tock Seng Hospital, Singapore, Singapore.

Published: 16 June 2015

${ }^{1}$ Infectious Diseases, Tan Tock Seng Hospital, Singapore, Singapore Full list of author information is available at the end of the article 
doi:10.1186/2047-2994-4-S1-P189

Cite this article as: Ang et al:: "Screening at the door" - continuous rapid molecular screening for MRSA at emergency department is efficacious and effective. Antimicrobial Resistance and Infection Control 2015 4(Suppl 1):P189.

Submit your next manuscript to BioMed Central and take full advantage of:

- Convenient online submission

- Thorough peer review

- No space constraints or color figure charges

- Immediate publication on acceptance

- Inclusion in PubMed, CAS, Scopus and Google Scholar

- Research which is freely available for redistribution

Submit your manuscript at www.biomedcentral.com/submit

C Biomed Central 